\title{
Komunální odpadní voda jako diagnostické médium hlavního města Prahy
}

\section{VĚRA OČENÁŠKOVÁ, PETR TUŠIL, DIANA MAREŠOVÁ, DANICA POSPÍCHALOVÁ, NIKOLA CIELECKÁ}

Klíčová slova: epidemiologický přístup k odpadním vodám - nezákonné drogy - nikotin - alkohol - monitoring

\section{SOUHRN}

Přispěvek informuje o pravidelném, téměř dvouletém monitoringu komunálních odpadních vod na vybraných odběrových místech pražské stokové sítě. V komunálních odpadních vodách jsou sledovány vybrané nezákonné drogy (napr. metamfetamin, MDMA, THC, kokain), nikotin a jeho metabolity a metabolit ethanolu ethylsulfát. $V$ tomto článku jsou prezentovány výsledky z prvního roku projektu, ze kterých jsou zřejmé výrazné rozdíly ve spotřebě jednotlivých drog $v$ různých částech Prahy. Pro potřeby projektu byly rozšířeny analytické metody stanovení sledovaných látek. Součástí řešení projektu je Socioekonomická studie prostorového rozložení obyvatelstva a identifikace rizikových oblastí z hlediska životního stylu obyvatelstva (ACCENDO, z. ú.).

\section{ÚVOD}

Analýza odpadních vod je "relativně" jednoduchá záležitost. S rozvojem instrumentální techniky v této oblasti jsme schopni při využití špičkových, vysoce citlivých analytických př́strojů zjistit př́tomnost jednotlivých látek v subnanogramových množstvích. Koncept IV volně navazuje na projekt "Stanovení množství nelegálních drog a jejich metabolitů v komunálních odpadních vodách - nový nástroj pro doplnění údajů o spotřebě drog v České republice", v jehož rámci byla sledována i kontaminace komunálních odpadních vod ve vybraných stokách kanalizační sítě hlavního města Prahy. Jedním z hlavních výstupů tohoto projektu byla Metodika [1], která byla využita také pro měření v tomto konceptu, v němž budou získány aktuální údaje o spotřebě nezákonných látek a údaje o nově sledovaných markerech.

Smyslem projektu je získat objektivní údaje, tzn. i údaje od té části populace, která nebyla zahrnuta do dotazníkových akcí na monitorované téma, nemá zdravotní potíže spojené s užíváním nezákonných látek atd.

Základ epidemiologie odpadních vod (wastewater-based epidemiology WBE) byl položen na přelomu let 1999 až 2000 vyslovením hypotézy, že ke komunální odpadní vodě Ize přistupovat jako ke zředěnému vzorku moči [2] a poprvé byla aplikována v povodí řeky Pád [3]. Zpočátku byl epidemiologický přistup k odpadním vodám využíván ke sledování spotřeby nezákonných látek v monitorované lokalitě a k upřesnění odhadu prevalence a užívání drog v populaci. Od doby svého vzniku se tento obor velmi rychle rozvijí a díky stále se zdokonalující analytické technice je možno sledovat široké spektrum látek ve velmi nízkých koncentracích. Na obr. 1 je schematické znázornění epidemiologického prístupu k odpadním vodám.

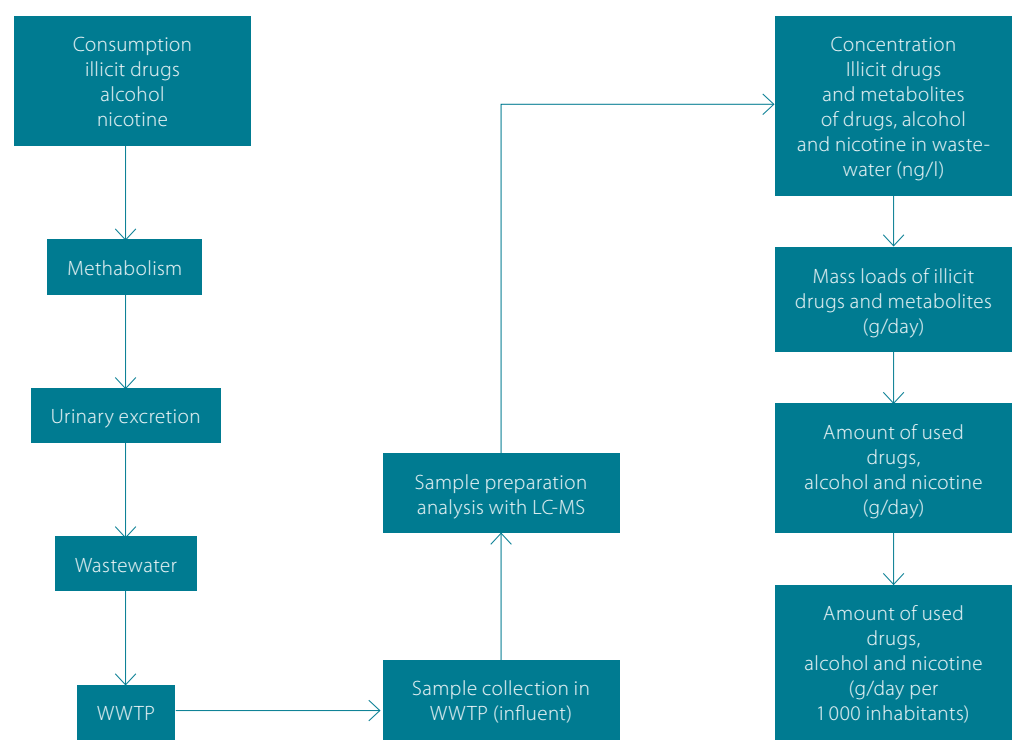

Obr. 1. Schematické znázornění epidemiologického prístupu k odpadním vodám Fig. 1. Schematic presentation of wastewater based epidemiological approach

Komunální odpadní vody obsahuji komplexní směs chemických látek včetně humánních metabolitů - biomarkerů. Kvantitativní měření těchto specifických látek poskytne informaci např. o způsobu stravování, zdravotním stavu obyvatelstva, výskytu chorob, spotřebě alkoholu, léčiv a expozici populace environmentálním kontaminantům, např. pesticidům.

Ve VúV TGM, v. v. i., je od počátku letošního roku řešen projekt: Čistá voda zdravé město: Komunální odpadní voda jako diagnostické médium hlavního města Prahy. Do řešení Konceptu IV jsou zapojeny hydrochemické laboratoře z odboru analýz a hodnocení složek životního prostředí (Praha) a ostravské pobočky. Vedle nezákonných látek a některých léčiv jsou sledovány také metabolity alkoholu (ethylsulfát), nikotinu (kotinin a trans-3-hydroxykotinin) a pesticidů. Monitoring bude probíhat po dobu dvou let na vybraných místech kanalizační sítě hlavního města Prahy. Plánovaným výstupem je mapová vrstva do Geoportálu hl. m. Prahy, do které bude v prípadě pravidelného monitoringu zaznamenávána např. spotřeba drog v jednotlivých částech Prahy.

Součástí řešení projektu je také Socioekonomická studie prostorového rozložení obyvatelstva a identifikace rizikových oblastí z hlediska životního stylu obyvatel. Tuto studii zpracovává jako subdodávku projektu společnost ACCENDO - Centrum pro vědu a výzkum, z. ú. 
Tabulka 1. Seznam monitorovaných látek

Table 1. List of monitored substances

\section{Skupina látek}

\begin{tabular}{|c|c|}
\hline \multirow{10}{*}{ „Klasické“ drogy } & 11-nor-9-karboxy-delta-9-THC \\
\hline & 3,4-methylen-dioxy-metamfetamin \\
\hline & metamfetamin \\
\hline & amfetamin \\
\hline & kokain \\
\hline & kokaethylen \\
\hline & benzoylekgonin \\
\hline & diethylamid kyseliny lysergové \\
\hline & heroin \\
\hline & morfin \\
\hline \multirow{6}{*}{ Substituční léčba } & metadon \\
\hline & $\begin{array}{l}\text { 2-ethyliden-1,5-dimethyl-3,3-difenylpyroli- } \\
\text { din (EDDP) }\end{array}$ \\
\hline & buprenorfin \\
\hline & ethylkatinon \\
\hline & pentedron \\
\hline & metylon \\
\hline
\end{tabular}

Nové syntetické drogy

\begin{tabular}{l}
\hline 4-methylethkatinon \\
\hline mefedron (4-methylmethkatinon) \\
\hline normefedron \\
\hline alfa-pyrolidinovalerofenon
\end{tabular}

\begin{tabular}{ll}
\hline \multirow{2}{*}{ Zneužívaná léčiva } & \multicolumn{1}{c}{ cis-tramadol } \\
\cline { 2 - 2 } nordiazepam \\
\cline { 2 - 2 } Nentanyl \\
\hline \multirow{2}{*}{ norfentanyl } \\
\hline Metin a jeho metabolity & kotinin \\
\cline { 2 - 2 } & trans-3-hydroxykotinin \\
\hline
\end{tabular}

Prekurzor pro výrobu drog efedrin

\section{ZDU゚VODNĚNÍ REALIZACE DÍLČÍHO KONCEPTU A IDENTIFIKACE TRŽNÍCH PŘÍLEŽITOSTÍ}

Zdůvodnění realizace projektu je již částečně uvedeno v předchozí kapitole. Cílem je získat aktuální data o spotřebě drog v jednotlivých částech Prahy (podle možností odběru na jednotlivých kanalizačních stokách), stejně tak jako o dalších látkách, které jsou v projektu sledovány. V rámci Konceptu IV je sledováno 29 látek. Jejich seznam je k dispozici v tabulce 1. Uvedené látky se dosud pravidelně nemonitorují, nejsou podchyceny př́slušnou legislativou. Zjištění jejich výskytu a koncentrací v odpadních vodách je významné nejen z výše uvedených důvodů, ale vzhledem k tomu, že některé z těchto látek nejsou zcela odstraněny $v$ procesu čištění odpadních vod, dostávají se i do vod povrchových, ve kterých mohou mít dopad na životní prostředí.
Získaná a analyticky zpracovaná data budou interpretována prostřednictvím mapového portálu. Potenciální možností je využití Geoportálu hl. m. Prahy, tzn. že výstupy projektu budou mít podobu mapových vrstev a databází, které by Magistrát hl. m. Prahy jakožto koncový uživatel výsledkủ šiřil přes svůj Geoportál.

Na základě analýzy a měření v odpadních vodách budou vytvořeny metody pro hodnocení účelnosti, efektivity a hospodárnosti opatření prevence a kontroly užívání zmíněných látek. Metody budou nastaveny tak, aby byly využitelné pro různé typy hodnocení (ex-ante, ex-post, on-going atd.).

\section{PRŮBĚH ŘEŠENÍ PROJEKTU}

\section{Odběry a základní předúprava vzorků}

Ve spolupráci s pracovníky úČOV bylo vybráno šest odběrových profilu na kanalizační síti hlavního města Prahy, byl připraven plán vzorkování a domluveny podmínky vzorkování a dopravy vzorků do laboratoře VúV TGM, v. v. i. Odběrové profily jsou na celkovém př́toku na ÚČOV a dále potom na jednotlivých stokách - ACK, B, D, E a F. Odběry probíhaly od začátku dubna 2018, v roce 2018 přibližně ve čtyřdenních intervalech, v roce 2019 v osmidenních intervalech. Kromě těchto odběrů byla v roce 2019 ještě realizována týdenní monitorovací kampaň pro mezinárodní projekt SCORE. Odebírány byly 24hodinové slévané vzorky komunální odpadní vody. Vzorky se odebírají do čistých vzorkovnic z vhodného materiálu (sklo, polypropylen (PP)). Po dopravě do laboratoře jsou tyto vzorky dále zpracovány zavedenými operačními postupy.

Na obr. 2 jsou ilustrační záběry z odběru 24hodinových slévaných vzorků ve stokové síti hlavního města Prahy.

Na obr. 3 je mapa pražské stokové sítě s vyznačením oblastí spadajících pod jednotlivé stoky.

Kanalýze se použije alikvotní část odebraného vzorku, konzervace se neprovádí. Po odběru se vzorky uchovávají v chladu a temnu při teplotě do $8{ }^{\circ} \mathrm{C}$. Nižší teplota uchování vzorků není závadou. Pokud nelze vzorek analyzovat do 72 h po odběru, vzorek je zamražen a do vlastní analýzy je skladován při teplotě $-20 \pm 4^{\circ} \mathrm{C}$. Nižší teplota uchování vzorků není závadou. Před vlastním

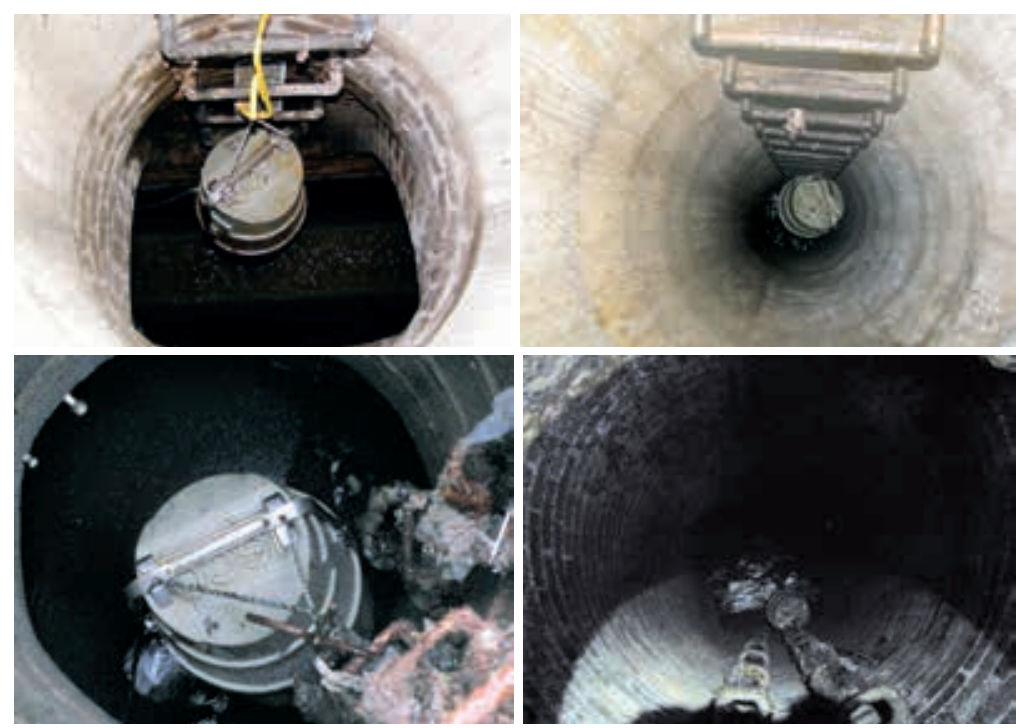

Obr. 2. Ilustrační záběry z odběru vzorků komunální odpadní vody

(zdroj: Pražské vodovody a kanalizace, a. s.)

Fig. 2. Illustrative shots of municipal wastewater sampling 


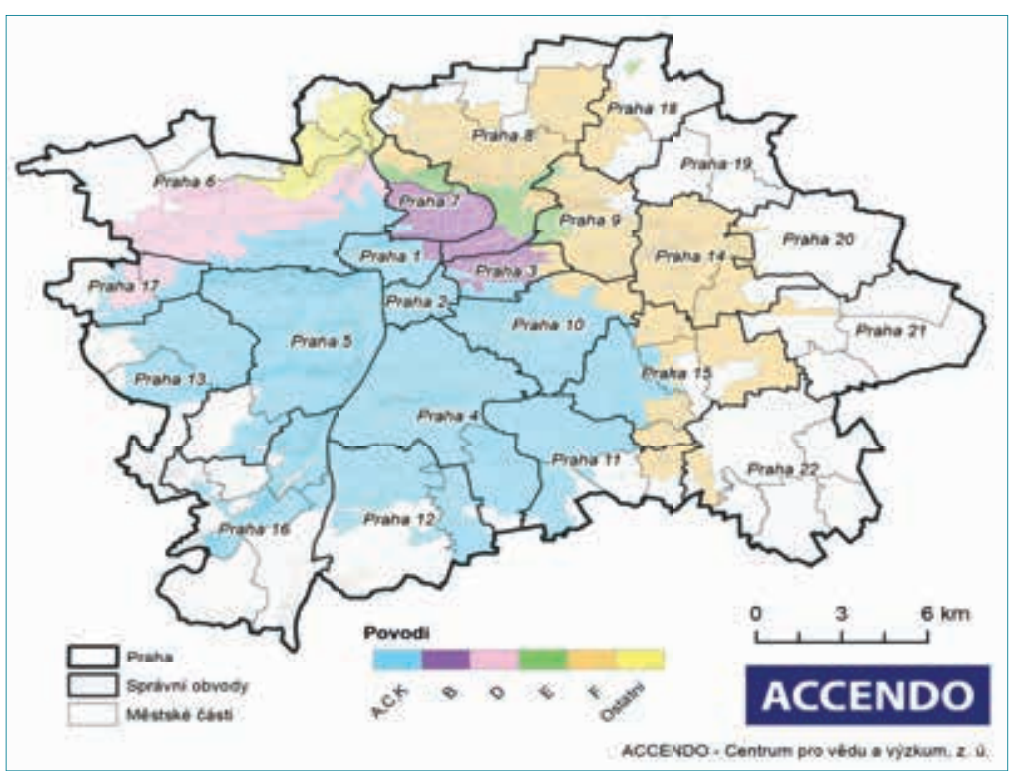

Obr. 3. Pražská stoková sít (zdroj: Pražské vodovody a kanalizace, a. S., ACCENDO) Fig. 3. Prague sewer network

stanovením jsou vzorky odstředěny (4 500 ot./min, 15 min) a filtrací přes jednorázové membránové filtry z regenerované celulózy o porozitě $0,45 \mu \mathrm{m}$ jsou ze vzorku odstraněny pevné částice.

\section{Vývoj analytických metod - zavedení postupů pro stanovení nikotinu a jeho metabolitů, ethylsulfátu (metabolit ethanolu) a nových psychotropních látek v odpadní vodě}

Metodika stanovení nezákonných látek (drog), která byla v laboratoři zavedena v rámci řešení projektu „Stanovení množství nelegálních drog a jejich metabolitů v komunálních odpadních vodách - nový nástroj pro doplnění údajů o spotřebě drog v České republice" [1], byla pro potřeby projektu Čistá voda - zdravé město rozšířena o stanovení nových psychotropních látek. Pro stanovení nikotinu a jeho metabolitů a stanovení ethylsulfátu byly zavedeny dvě zcela nové metody. Tyto metody byly validovány a akreditovány.

V návaznosti na chemické vlastnosti látek byly použity následující postupy:

- stanovení vybraných drog metodou kapalinové chromatografie s on-line prekoncentrací a hmotnostní detekcí v ESI + módu,

- stanovení vybraných drog metodou kapalinové chromatografie s on-line prekoncentrací a hmotnostní detekcí v ESI - módu),

- stanovení nikotinu a jeho vybraných metabolitů metodou kapalinové chromatografie s on-line prekoncentrací a hmotnostní detekcí v ESI + módu),

- stanovení ethylsulfátu metodou kapalinové chromatografie s hmotnostní detekcí v ESI - módu.

Analytické metody jsou podrobně popsány v článku "Stanovení vybraných drog a jejich metabolitů v odpadních vodách metodou kapalinové chromatografie" (autoři: Pospíchalová, D. a kol.), který je rovněž prezentován v tomto čísle VTEI.

\section{Zpětná kalkulace spotřeby monitorovaných látek}

Ze zjištěných koncentrací (ng/l) sledovaných látek v analyzovaných vzorcích komunální odpadní vody Ize zjištovat další údaje, jako jsou např. denní odnosy monitorovaných látek či jejich spotřeba vyjádřené v g/den/1 000 obyvatel (jednotka hmotnosti může být podle potřeby jiná). K těmto přepočtưm je třeba znát denní průtok odpadní vody v den odběru 24hodinového slévaného vzorku a počet obyvatel napojených na kanalizační sít v dané oblasti. Tak zjistíme denní odnosy jednotlivých látek. Ke zjištění spotřeby konkrétní látky je nezbytné ještě tzv. korekční (přepočítávací) faktor, který se stanoví jako poměr molekulárních hmotností monitorované látky a specifické látky (metabolitu nebo nezměněné monitorované látky) násobený prưměrnou procentuální metabolizací monitorované látky na zvolený metabolit, prípadně nemetabolizací, prochází-li monitorovaná látka organismem částečně nezměněna.

Hodnoty denních průtoků komunální odpadní vody pro potřeby projektu poskytují Pražské vodovody a kanalizace, a. s. Odhad počtu obyvatel náležících do jednotlivých spádových oblastí stokové sítě na základě dat ze sčítání lidu, domů a obyvatel a registru obyvatel provedla společnost ACCENDO, z. ú. Korekční faktory jsou použity z literárních zdrojů.

\section{Non-target (necílová) analýza}

Necílová analýza slouží ke zjištění prítomnosti dalších látek ve vzorku. Hydroanalytické laboratoře VúV TGM, v. v. i., nedisponují vhodným př́strojovým vybavením pro tento typ analýz, proto byly vybrané vzorky odpadní vody předány k analýze do Laboratoře forenzní analýzy biologicky aktivních látek na VŠCHT v Praze. Výsledky analýz se vyhodnocují.

\section{Subdodávka - Socioekonomická studie}

Součástí projektu je také zpracování Socioekonomické studie prostorového rozložení obyvatelstva a identifikace rizikových oblastí z hlediska životního stylu obyvatel. Tato studie byla řešena subdodavatelsky společností ACCENDO Centrum pro vědu a výzkum, z. ú.

Detailnější informace o této studii jsou uvedeny v článku „Využití moderních analytických metod při řešení rizik a tvorbě územních strategií" (autoři: Hrušková, A. a Hruška, L.), který je také prezentován v tomto čísle VTEl.

\section{PŘÍKLADY VÝSLEDKU゚}

Odběry vzorků byly zahájeny v dubnu roku 2018, zpočátku byly monitorovány především „klasické” drogy, později (červenec 2018) byly doplněny i látky, pro které byly vyvíjeny nové metody. Odběry byly ukončeny v prosinci 2019. Výsledky jsou postupně zpracovávány.

Bylo odebráno a zanalyzováno cca 500 vzorků odpadních vod. Nálezy monitorovaných drog ze skupiny označené v tabulce 1 jako "klasické" drogy (s výjimkou heroinu a LSD, které nebyly nalezeny v žádném vzorku) a dalších látek (cis-tramadol, nordiazepam, nikotin a jeho metabolity, ethylsulfát a efedrin) byly pozitivní ve všech odebraných vzorcích. Téměř ve všech vzorcích byl nalezen metadon a jeho metabolit 22-ethylidene-1,5-dimethyl-3,3-diphenylpyrrolidine (EDDP). Fentanyl se vyskytuje $\vee$ koncentracích okolo meze stanovitelnosti. Buprenorfin a většina látek ze skupiny nových syntetických drog (NSD) nebyly nalezeny v žádném vzorku. Nálezy některých NSD (mefedron) jsou zcela ojedinělé - jednotky vzorků. Heroin je metabolizován na 6-acetylmorfin, který rychle degraduje, nepodařilo se ho stanovit v žádném, dosud v laboratoři odebraném, vzorku odpadních vod. Další metabolit této drogy, morfin, je však zároveň 


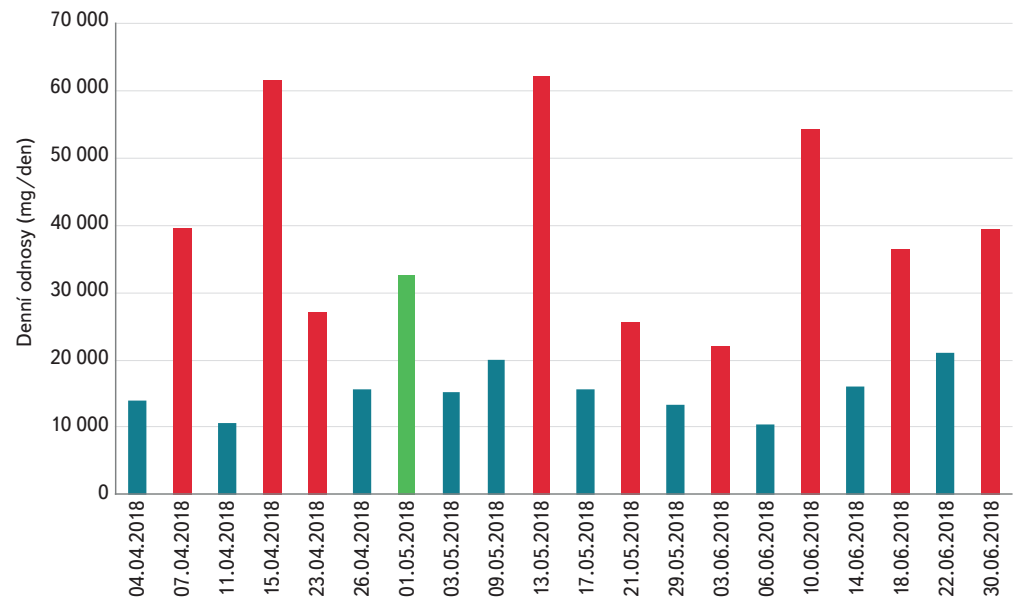

Obr. 4. Denní odnosy extáze (stoka ACK); modrou barvou jsou vyznačeny pracovní dny, červenou víkendové dny, zelenou státní svátek, kterému předcházelo „pálení čarodějnic"

Fig. 4. Daily mass loads of ecstasy (ACK sewer); working days are marked in blue, weekend days in red and in green is marked national holiday, which was preceded by "witch burning"

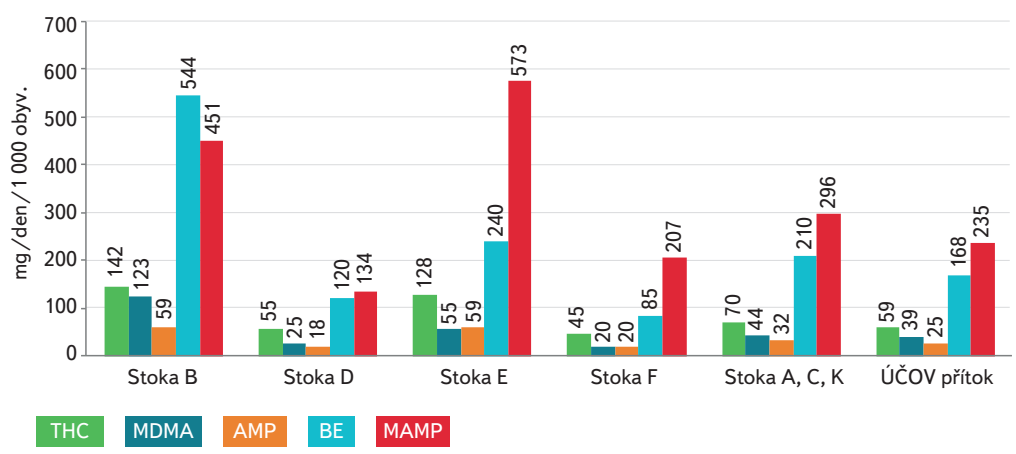

Obr. 5. Průměrná spotřeba vybraných nelegálních drog v mg/den/1 000 obyvatel; THC tetrahydrokanabinol (marihuana), MDMA - extáze, AMP - amfetamin, BE - benzoylek gonin, hlavní metabolit kokainu, MAMP - metamfetamin (pervitin)

Fig. 5. Average consumption of selected illegal drugs in mg/day/1,000 inhabitant; THC tetrahydrocannabinol (marijuana), MDMA - ecstasy, AMP - amphetamine, BE - benzoylecgonine, main metabolite of cocaine, MAMP - methamphetamine (meth, Crystal)

metabolitem i dalších látek, včetně preskribovaných léčiv. Určit, jaký podíl nálezů morfinu vznikl degradací heroinu, je prakticky nereálné. Typickou víkendovou drogou je extáze. Velmi dobře je to vidět na obr. 4.

Na dalších obrázcích jsou výsledky monitoringu odpadních vod za rok 2018. Výsledky za rok 2019 se ještě zpracovávají.

Na obr. 5 jsou velmi dobře vidět rozdíly mezi spotřebou různých drog v různých částech Prahy, mapa s vyznačením spádových oblastí jednotlivých stok je na obr. 3 .

$\checkmark$ českém prostředí není amfetamin př́liš užívanou drogou na rozdíl od západní Evropy. Je však také metabolitem metamfetaminu a nálezy v komunální odpadní vodě tomu odpovídají.

Spotřebě tabáku je věnován obr. 6. Důležitými metabolity jsou zejména kotinin a trans-3-hydroxykotinin, stabilní metabolity nikotinu. Nikotin se do odpadních vod dostává nejen jako nezmetabolizovaný z vykouřených cigaret a dalších tabákových výrobků, ale také např. z prípravků využivaných při odvykání $[4,5]$.

Alkohol je další drogou, i když legální, která byla v rámci projektu monitorována. Jeho spotřeba je sledována prostřednictvím metabolitu ethysulfáfu.

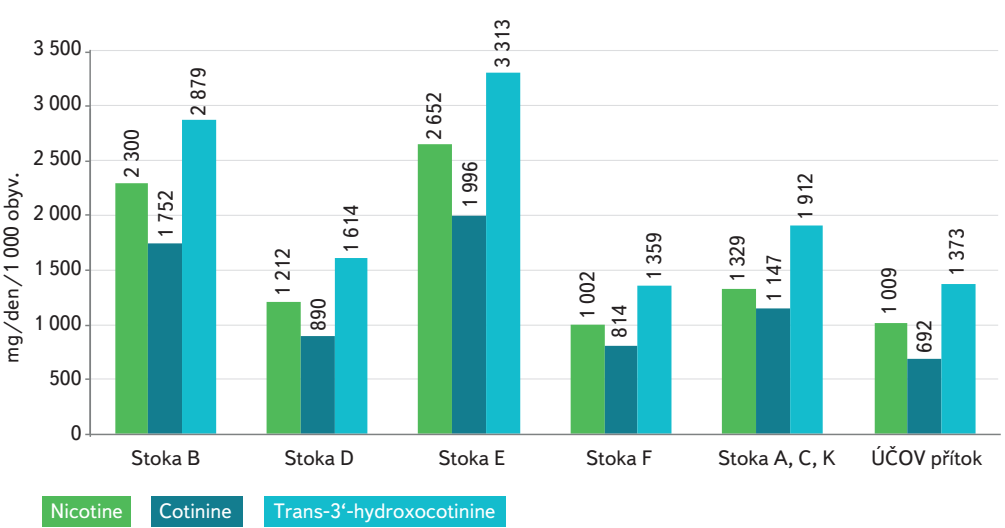

Obr. 6. Průměrná spotřeba tabáku a jeho metabolitů v mg/den/1 000 obyvatel Fig. 6. Average consumption of tobacco and its metabolites in mg/day/1,000 inhabitants

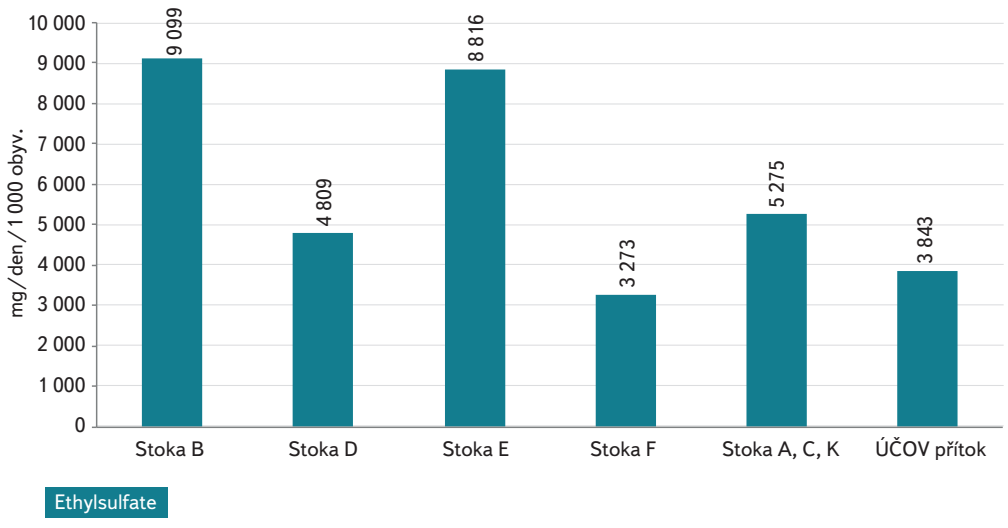

Obr. 7. Průměrná spotřeba alkoholu v mg/den/1 000 obyvatel (ethylsulfát - monitorovaný stabilní metabolit ethanolu)

Fig. 7. Average alcohol consumption in mg/day/1,000 inhabitants (ethyl sulfate - monitored stable metabolite of ethanol)

Přestože se tímto způsobem vylučuje pouze $<0,1$ \% zkonzumovaného alkoholu [6], nálezy v odpadní vodě jsou jednoznačně nejvyšší ze všech monitorovaných látek (obr.7).

\section{ZÁVĚR}

V rámci projektu bylo celkem odebráno a zpracováno téměř 500 vzorků odpadních vod a provedeno cca 2000 analýz. Výsledky jsou postupně zpracovávány, jsou prováděny zpětné prepočty odnosů jednotlivých sledovaných látek jak $\checkmark$ dílčích monitorovaných oblastech (jednotlivé stoky pražské kanalizační sítě, tak na př́toku na ÚČOV hlavního města Prahy). Z uvedených výsledků jsou zřejmé výrazné rozdíly ve spotřebě drog v rozdílných částech Prahy. Např́klad spotřeba kokainu je nejvyšší v oblastech blízko centra, která jsou současně i oblíbenými čtvrtěmi k bydlení. Byla vypracována Socioekonomická studie prostorového rozložení obyvatelstva a identifikace rizikových oblastí z hlediska životního stylu obyvatelstva, subdodavatelem této studie je institut ACCENDO - Centrum pro vědu a výzkum, z. ú. Laboratoř se zapojila do mezinárodního projektu SCORE, jehož součástí je vedle týdenního monitoringu komunální odpadní vody ve sledované lokalitě, v tomto prípadě Prahy, i účast v mezilaboratorním porovnání zkoušek. Výsledky tohoto monitoringu budou prezentovány na stránkách EMCDDA (European monitoring centre for drugs and drug addiction). 


\section{Poděkování}

Projekt "Čistá voda - zdravé město: Komunální odpadní voda jako diagnostické médium hlavního města Prahy" financuje hlavní město Praha v rámci Operačního programu Praha - pól rưstu ČR, Registrační číslo: CZ.071.02/0.0/0.0/16_040/0000378.

Realizace projektu by nebyla možná bez úzké spolupráce s akciovou společností Pražské vodovody a kanalizace.

\section{Literatura}

[1] OČENÁŠKOVÁ, V. a kol. Metodika aplikace epidemiologie odpadních vod pro stanovení odnosu nezákonných látek (drog) v České republice. Certifikovalo České ekologické manažerské centrum, 28. pluku 524/25, 10100 Praha 10. Certifikováno 29. 12. 2015.

[2] DAUGHTON, CH.G. and TERNES, T.A. Pharmaceuticals and personal care products in the environment: agents of subtle change? Environmental Health Perspectives, 1999, 107 (suppl 6), p. 907-938. DOI: 10.1289/ehp.99107s6907. ISSN 0091-6765. Dostupné z: https://ehp.niehs.nih.gov/doi/10.1289/ ehp.99107s6907

[3] DAUGHTON, CH.G. Illicit Drugs: Contaminants in the Environment and Utility in Forensi Epidemiology Reviews of Environmental Contamination and Toxicology, 2011, Vol. 210, p. 59-110. DOl: 101007/978-1-4419-7615-4 3. ISBN 978-1-4419-7614-7. Dostupné z: http.//link.springercom/ 10.1007/978-1-4419-7615-4_3

[4] CASTIGLIONI, S., SENTA, I., BORSOTTI, A., DAVOLI, E., and ZUCCATO, E. A novel approach for monitoring tobacco use in local communities by wastewater analysis. Tobacco Control, 2014, 24, 1 p. 38-42. DOI: 10.1136/tobaccocontrol-2014-051553. ISSN 0964-4563. Dostupné z: http://tobaccocontrol. bmi.com/lookup/doi/10.1136/tobaccocontrol-2014-051553

[5] ORT CH VAN NUIUS, A.LN BERSET, JD et al Spatial differences and temporal changes in illicit drug use in Europe quantified by wastewater analysis. Addiction, 2014, 109, 8, p. 1338-1352. DOI: 10.1111/ add.12570. ISSN 09652140. Dostupné z: http://doi.wiley.com/10.1111/add.12570

[6] MASTROIANNI, N., LOPEZ DE ALDA, M., and BARCELO, D. Analysis of ethyl sulfate in raw wastewater for estimation of alcohol consumption and its correlation with drugs of abuse in the city of Barcelona. Journal of Chromatography A., 2014, 1360, p. 93-99. DOI: 10.1016/j.chroma.2014.07.051. ISSN 00219673. Dostupné z: http://linkinghub.elsevier.com/retrieve/pii/S0021967314011443

\section{MUNICIPAL WASTEWATER AS \\ A DIAGNOSTIC MEDIUM OF THE CITY OF PRAGUE}

\section{OCENASKOVA, V.'; TUSIL, P.'; MARESOVA, D.'; POSPICHALOVA, D.'; CIELECKA, N.'}

'TGM Water Research Institute, p.r.i.

${ }^{2}$ Czech Hydrometeorological Institute

Keywords: wastewater-based epidemiology illicit drugs - nicotine - alcohol - monitoring

The article informs about regular, almost two-year long monitoring of municipal wastewater at selected sampling points of the Prague sewerage network. Selected illicit drugs (e.g. methamphetamine, MDMA, THC, cocaine), nicotine and its metabolites and the ethanol metabolite ethyl sulphate are monitored in municipal wastewater. Results of the first year of the project are presented in this article. There are obvious differences in consumption of individual drugs in different parts of Praque.

For the purposes of the project, analytical methods for the determination of monitored substances were extended.

The project includes a Socio-economic study of spatial distribution of the population and identification of risk areas in terms of population lifestyle (ACCENDO, z. ú.).

\section{Autoři}

Ing. Věra Očenášková

凶vera.ocenaskova@vuv.cz

Ing. Petr Tušil, Ph.D., MBA ${ }^{2}$

凶p petr.tusil@chmi.cz

RNDr. Diana Marešová, Ph.D.

凶diana.maresova@vuv.cz

Ing. Danica Pospíchalová

凶danica.pospichalova@vuv.cz

\section{Ing. Nikola Cielecká}

网 nikola.cielacka@vuv.cz

'Výzkumný ústav vodohospodářský T. G. Masaryka, v. v. i.

Český hydrometeorologický ústav

Příspěvek prošel lektorským řízením. 